\title{
Investigating the Creativity of Children in Early Childhood Education Institutions
}

\author{
Zeynep Dere \\ Department of Child Development, Medical School of Izmir Odemiş, Ege University, Turkey
}

Copyright $\mathrm{C} 2019$ by authors, all rights reserved. Authors agree that this article remains permanently open access under the terms of the Creative Commons Attribution License 4.0 International License

\begin{abstract}
Early childhood education institutions are referred to preschool, nursery school and practicum schools that educate young children. Preschool curriculum was developed for children in the preschool education institutions to provide a rich learning experience and to help healthy growth. Creativity is fundamental for the preschool curriculum and can be defined as a procedure to create original things. Preschool teachers should provide children with materials to trigger their imagination, should provide opportunities to imagine and to explain their ideas, should appreciate children's individuality, and should encourage their different viewpoints. They also should encourage children to participate in creative games, should care about children's new products, and value them. Moreover, children's creativity should be appreciated, and children should be given confidence. In this study, it is aimed to investigate the creativity of children in the preschool. A simple causal design with pre-and post-test with a single group was used in the study. The participants consisted of 184 children (96 boys, 88 girls) enrolled in preschool and nursery schools belong to Ministry of Education located in Ankara during the 2014-2015 academic year. Figural Creativity Form A and B of Torrance Tests of Creative Thinking were used as pre- and post-tests. The results showed that preschool curriculum increased children's creativity in a positive way.
\end{abstract}

Keywords Creativity, Preschool Education, Preschool Education Program

\section{Introduction}

[1] Early childhood education institutions are referred to preschool, nursery school and practicum schools that educate young children. [2] The curriculum has been developed for children in the early childhood education institutions to provide them with rich learning experience. The aim is to maximize the motor, social-emotional, linguistic and cognitive development of children and to enable them to gain self-care skills and to be ready for primary school, as well. One of the basic principles of preschool education is the mobilization of imagination and creativity in children.

Creativity has not been considered as an individual field in the 2013 preschool curriculum of the Ministry of National Education. However, creativity is the basis of the curriculum. Children must express themselves in different and unique ways in conditions that appropriate to their learning needs and learning styles. To enable this, relevant opportunities should be provided. All the activities to be planned should support creativity. Therefore, understanding creativity is very important for preschool education.

$[3,4]$ Creativity can be referred to as the process of producing original things. It is the development of original opinions and creation of new products and inventions by an individual. [5] The creativity is different in each individual and even the creativity processes within each individual are different. [6] The important thing for the creative activities to take place in the preschool curriculum for children in the preschool period is the availability of appropriate learning techniques and rich materials.

[7] According to Bloomberg (1973), creativity is the total of the skills in the divergent thinking category. These categories have been defined as fluency, flexibility, originality, and elaboration. Fluency is the ability to produce and the number of ideas on the topic. Flexibility is the change of perspectives to the problems. Originality is producing unique ideas. Elaboration is detailing the added ideas.

[8] Vygotsky (1962) developed the concept of the Zone of Proximal Development (ZPD) for early childhood. Accordingly, children experience learning with peers and adults. Their interaction during the collaboration with their peers and adults offers opportunities for the development of creativity. Therefore, providing a creative environment for children by adults in the early period is very important. [3] Children do not fear making mistakes and taking risks 
in a creative atmosphere. Children's ideas are respected and their brainstorming attempts are reacted positively. Therefore, the positive attitudes of preschool teachers are another factor important in creativity.

$[3,9,10,11]$ There are a number of points that preschool teachers should consider to support the creativity of children. Preschool teachers should provide rich materials that mobilize the imagination of children, offer opportunities for children to dream, provide opportunities to express their ideas, appreciate their individuality and encourage different perspectives. They should encourage children to participate in creative games and care about and value their new products. Moreover, they should appreciate children's creativity and assure them. Studies show that creativity can be improved.

Faizi, Azari, and Maleki [12] investigated the design settings that improve the creativity of children. According to the study result, the rich stimulating environment provided to children and active participation of children in activities together with natural materials positively improve the creativity of the children.

Yildız [13] studied with a total of 24 children to examine the effects of creativeness education program on the social and cognitive development of children. In her study that she conducted with four-five-year old children, she provided a creativeness education program to 12 children that she determined as the experimental group. As a result of the study, she found significant differences between the groups who received and did not receive creativeness education program in favor of the children who received creativeness education program in the cognitive development and social development areas.

Cheung [14] investigated the effect of creative movement activities applied on preschool children on the creativity of children. She studied at three kindergartens with 12 children who received education at these kindergartens and with 3 class teachers. She practiced creative movement activities based on four basic principles: introduce the theme, acquire and explore movement skills, creation-expression, and performance-appreciation. According to the research findings, the creativity of children can be supported and improved through creative movement activities.

Rizi, Yarmohamadiyan, and Gholami [15] studied with 60 children who were continuing to kindergarten, to determine the effect of the group plays on the development of creativity in six-year-old children. 30 of the children were determined as the experimental group and 30 as the control group. The experimental group was trained through group plays and both groups participated in the post-test after the completion of the training program. The results showed that creativity scores of children positively increased due to group plays training. It was determined that the creative skills of children can be developed through group play activities.

Alfonso-Benlliure, Melendez, and Garcia-Ballesteros
[16] evaluated the effects of the creativity intervention program developed for preschool children. The creativity intervention program was applied to 44 children between the ages of 60-71 months who were continuing to kindergarten. As a result of the research, it was found that the quality of creativeness in children's products developed due to the creativity intervention program.

Dziedziewicz, Oledzka, and Karwowski [17] studied with 128 children who were continuing to kindergarten, to examine the creativity development in children aged between four and six years. The children were divided into two groups as experimental and control. They applied a creative doddle-book program on 67 children in the experimental group for five weeks. According to the research results, the doodle-book program positively increased the imagination and creativity development of the children aged four to six years.

Garaigordobil and Berrueco [18] searched the effects of the play program applied to preschool children on the creativity of children. According to the study results, they determined that the play program was effective in developing children's creative behaviors.

Besides the implementation of creativity education programs to improve the creativity of preschool children, it can be expressed that activities such as play activities, drama activities, early literacy activities are also improve the creativity. In addition, it can be said that the rich stimulating environment that is created in the class and that supports creativity affects the creativity of the children positively.

In the study, it was aimed to investigate the creativity of children in preschool education institutions. For this purpose, the following sub-questions were sought for an answer. Does preschool education affect the creativity of children in terms of the following dimensions?

1. Fluency,

2. Originality,

3. Elaboration,

4. Abstractness of titles,

5. Resistance to premature closure,

6. Overall figure,

7. Overall creativity strength ratings,

8. Overall figural creativity.

\section{Materials and Methods}

Information on MoNE 2013 preschool curriculum, research design, study group, data collection tool, data collection, and analysis are included in this section of the research.

\subsection{Research Model}

One group pretest-posttest simple experimental design was used in the research. [19] In this design, the effect of 
an experimental process is tested on a single group. Dependent variable measurements of the subjects are obtained using the same subjects and same test measurement tool as the pre-test prior to the implementation and post-test after the implementation. If the data obtained indicate a significant difference between the pre-test and the post-test, it is assumed that this difference is due to the effect of the implementation. The information about the research design is given in Table 1. In this context, the Torrance Creative Thinking Test (Figural form A, Figural form B) was implemented to the single group as the pre-test and post-test and the MoNE's 2013 Preschool curriculum was used as the procedure.

Table 1. Research design

\begin{tabular}{cccc}
\hline Group & Pre-test & Procedure & Post-test \\
\hline $\mathrm{G}$ & $\mathrm{O} 1$ & $\mathrm{X}$ & $\mathrm{O} 2$ \\
\hline & Torrance & & Torrance \\
& Creative & MoNE's 2013 & Creative \\
& Thinking Test & Preschool & Thinking Test \\
& (Figural form A, & curriculum & (Figural form A, \\
& Figural form B) & & Figural form B) \\
\hline
\end{tabular}

G: Group; O1: Pre-test; X: Procedure; O2: Post-test

\subsection{Study Group}

The appropriate case study group was used in the selection of the study group. [20] The appropriate case study group is the selection of individuals and groups who are easily researched. The researcher can choose the individuals and groups to collect the data easily.

\subsection{Data Collection Tool}

[21, 22] Figural Form A and Figural Form B of the Torrance Creative Thinking Test (TCTT), which was developed by Torrance (1966), were used. General Information Form: It includes the information about children including name, date of birth on the cover page of Torrance Creative Thinking Tests. Creative Thinking Tests: It consists of four forms that are Verbal Form A, Verbal Form B, Figural Form A and Figural Form B of Creative Thinking Tests. Tests that measure creative thinking performance were developed by E. Paul Torrance. In the measurement tool published in 1966, the figural form consists of three activities: compose a drawing; finish a drawing; and compose a different drawing parting from parallel lines. The figural forms consist of Fluency, Originality, Elaboration, Abstractness of Titles, Resistance to Premature Closure, Overall Figure, Overall creativity Strength Rating, and Overall Figural Creativity factors. The verbal form consists of seven subtests that are asking question, making guesses about causes, making guesses about consequences, improvement of a product, unusual uses, unusual questions, and supposing. Verbal Form $\mathrm{A}$ and $\mathrm{B}$ and Figural Form $\mathrm{A}$ and $\mathrm{B}$ are similar to each other. It is a measurement tool, which has been widely used since 1966 in studies conducted on creativity. In our country, the validity-reliability and linguistic equivalence studies of both the figural and verbal forms $\mathrm{A}$ and B of the test for preschool, primary school, high school, and adults were conducted by Aslan (1999). In the Turkish adaptation studies of the test, the implementation was conducted on all preschool, primary school, high school, and adult groups. Efficient conclusions were obtained in linguistic equivalence, reliability and validity studies. For the validity and reliability of the measurement tool, the tests were translated into Turkish by three experts and a single form was obtained by comparing these three forms. The Turkish and English forms developed were implemented on 30 individuals who knew both languages. Significant results between 0.64-0.86 and at 0.01 level were obtained for the Verbal Form of the test, whereas significant results between 0.50 and 0.96 at 0.01 and 0.05 level were obtained for the figural form. In addition, the differences between the mean scores in English and Turkish forms were analyzed using appropriate methods for all types of scores. In this way, the Torrance Creativity tests have become usable with Turkish instructions.

\subsection{Ministry of National Education Preschool Curriculum}

Early childhood education is regulated and monitored by the MoNE. Its preschool curriculum is applied and followed by the institutions all around the Turkey. Achievements and type of the activities have not been listed in the curriculum yet, teachers plan their daily educational activities. Type of the activities, learning processes and materials may vary depending on the teachers' judgments and experiences. All teachers are supposed to lead children to reach targeted achievements using semi-structured activities.

The preschool curriculum is child-centered and focuses on learning by discovery. It offers active planning, practicing, coordination, questioning, research, discussion, and production opportunities to the children during the learning process. The physical environment of the children is flexible for the adaptation according to their family characteristics. It is a spiral curriculum that allows the acquisition and re-implementation of instructions in line with the requirements in the learning process. The curriculum, where different approaches and models are implemented, is eclectic. It is play-based, gives importance to family education, takes universal values into consideration, and encourages daily life experiences. The themes in the curriculum are not the purpose but the tools. It involves adaptations for children with special needs and multifaceted assessment.

There are achievements and instructions related to the development of creativity in the Preschool Curriculum (2013). For example, there is an instruction stating "Offers creative solutions for the problem" for the acquirement stating, "Finds a solution in case of problems" 
in the field of cognitive development. In the field of social and emotional development, it includes the acquirement stating "Expresses him/herself in a creative way". In addition, learning centers such as blocks, dramatic plays, art, books, science, music, sand, and water are included in the curriculum. These centers support creativity, as well. For example, there is an expression for block center stating that "It is a center that allows children to notice the figures of different sizes, shapes, and colors in the places where they are and the relations between these figures and to use their creativity through building-construction games by using different figures." The MoNE preschool curriculum involves activities of language, art, drama, music, movement, play, science, mathematics, early literacy and field trip. Creativity is planned as integral part of these educational activities. The targeted achievements related to creativity are placed in the learning process. Variety of the activities helps planning different achievements. Children engage in circle time activities at the beginning and at the end of the class. These activities are not considered as educational activity but aim to increase the readiness of the children to the activities and evaluating the learning experiences. Children play in three to five different educational activities every day based on the activity length.

\subsection{Data Collection}

For the pre-tests, Figural $\mathrm{A}$ and Figural $\mathrm{B}$ of the Torrance Creative Thinking Tests were applied by the researcher to the new kindergartner children in September (2014). Children involved in their educational activities for a semester. During the semester, children played in forty language, forty play, forty art, thirty science, thirty movement, thirty mathematics, twenty five drama, twenty five music, twenty five early literacy activities and one field trip. For the post-tests, Figural A and Figural B of the Torrance Creative Thinking Tests were applied by the researcher in May (2015) to the same children at the same kindergartens.

\subsection{Data Analysis}

The data collected from the study group were analyzed using SPSS package software. Firstly, the data obtained were analyzed whether they showed normal distribution. According to Shapiro-Wilk analysis among the normality test results, it was determined that the data showed normal distribution. Therefore, "paired sample t-test", which is one of the parametric tests and is appropriate for single subject designs, was used and the significance level was determined as 0.05 .

\section{Results}

\subsection{Demographic Findings}

The study group consisted a total of 184 children (96 boys, 88 girls) who received education in the preschools and nursery schools affiliated to the Ministry of National Education in Ankara in the academic year of 2014-2015. $41.9 \%$ of the children were at the age between $66-70$ months; $26.0 \%$ between $61-65$ months; $22.3 \%$ at the age of 71 months and over; and $9.8 \%$ between 56 and 60 months. Preschools and nursery classes in the districts of Keçiören (36 children), Etimesgut (35 children), Yenimahalle (35 children), Mamak (34 children), Altındağ (28 children) and Çankaya (16 children) were included in the study group.

\subsection{Findings Related to the Determination of the Effect of Preschool Education on Children's Creativity}

The study was conducted to examine the creativity of the children who were continuing to the preschool education institution. In this section of the research, the findings obtained from 184 children were included.

Answers were sought for the question of "Does the preschool education affect the creativity of children in terms of fluency, originality, elaboration, abstractness of titles, resistance to premature closure, overall figure, overall creativity strength ratings, overall figural creativity?". The results of the Paired Samples t-test for the comparison of the pre-test and post-test averages of the children in the Torrance Creativity Test Figural Creativity A and B Forms are given in Table 2. 
Table 2. The Difference between the Average Pre-Test-Post-Test Scores of Children in the Torrance Creativity Test Paired Samples t-Test Results

\begin{tabular}{|c|c|c|c|c|c|c|c|}
\hline $\begin{array}{l}\text { TCTT Form A and B } \\
\text { Factors }\end{array}$ & Test & $\mathbf{N}$ & $\overline{\mathbf{x}}$ & SD & df & $\mathbf{t}$ & $\mathbf{p}$ \\
\hline \multirow{2}{*}{ Fluency } & Pre-test & 184 & .948 & .3944 & \multirow{2}{*}{182} & \multirow{2}{*}{2.726} & \multirow{2}{*}{$.000 *$} \\
\hline & Post-test & 184 & 1.308 & 2.366 & & & \\
\hline \multirow{2}{*}{ Originality } & Pre-test & 184 & 1.479 & .5777 & \multirow{2}{*}{182} & \multirow{2}{*}{-3.975} & \multirow[t]{2}{*}{$.000 *$} \\
\hline & Post-test & 184 & 2.346 & 1.345 & & & \\
\hline \multirow{2}{*}{ Elaboration } & Pre-test & 184 & 2.338 & .7438 & \multirow{2}{*}{182} & \multirow{2}{*}{-2.583} & \multirow{2}{*}{$.000 *$} \\
\hline & Post-test & 184 & 2.852 & 1.818 & & & \\
\hline \multirow{2}{*}{ Abstractness of Titles } & Pre-test & 184 & 3.446 & .9266 & \multirow{2}{*}{182} & \multirow{2}{*}{-1.926} & \multirow{2}{*}{$.000 *$} \\
\hline & Post-test & 184 & 3.548 & 1.150 & & & \\
\hline \multirow{2}{*}{$\begin{array}{l}\text { Resistance to Premature } \\
\text { Closure }\end{array}$} & Pre-test & 184 & 2.203 & .7263 & \multirow{2}{*}{182} & \multirow{2}{*}{-1.802} & \multirow[t]{2}{*}{$.000 *$} \\
\hline & Post-test & 184 & 2.897 & .8967 & & & \\
\hline \multirow{2}{*}{ Overall Figure } & Pre-test & 184 & 2.639 & .8397 & \multirow{2}{*}{182} & \multirow{2}{*}{-1.947} & \multirow{2}{*}{$.000 *$} \\
\hline & Post-test & 184 & 3.492 & .9869 & & & \\
\hline \multirow{2}{*}{$\begin{array}{l}\text { Overall Creativity Strength } \\
\text { Ratings }\end{array}$} & Pre-test & 184 & .941 & .3617 & \multirow{2}{*}{182} & \multirow{2}{*}{-1.173} & \multirow{2}{*}{$.000^{*}$} \\
\hline & Post-test & 184 & 1.451 & .7594 & & & \\
\hline \multirow{2}{*}{ Overall Figural Creativity } & Pre-test & 184 & 2.233 & .8412 & \multirow{2}{*}{180} & \multirow{2}{*}{-2.011} & \multirow{2}{*}{$.000 *$} \\
\hline & Post-test & 184 & 4.588 & 2.021 & & & \\
\hline
\end{tabular}

$* \mathrm{p}<0.05$

According to Table 2, the average score of the children in the Torrance Creativity Test Fluency pre-test was $\overline{\mathrm{x}}=.948$ and it increased to $\overline{\mathrm{x}}=1.308$ in the post-test. This difference is significant in favor of the post-test $[\mathrm{t}(182)=2.726, p<0.05]$. In the Originality factor, the average score of the children in the pre-test was $\bar{x}=1.479$ and increased to $\bar{x}=2.346$ in the post-test. The difference between the pre-test and post-test was significant in favor of the post-test $[\mathrm{t}(182)=-3.975, \quad p<0.05]$. In the Elaboration factor, the average score in the pre-test was $\overline{\mathrm{x}}=2.338$ and increased to $\overline{\mathrm{x}}=2.852$ in the post-test. The difference in this factor was significant in favor of the post-test $[\mathrm{t}(182)=-2.583, p<0.05]$. In the Abstractness of Titles factor, the average score in the pre-test was $\bar{x}=3.446$, and increased to $\bar{x}=3.548$ in the post-test. This difference was significant in favor of post-test $[\mathrm{t}(182)=-1.926$, $p<0.05]$. The average score of the children in the pre-test of the Resistance to Premature Closure factor was $\bar{x}=$ 2.203 and it increased to $\bar{x}=2.897$ in the post-test. The difference in this factor was significant in favor of the post-test $[\mathrm{t}(182)=-1.802, p<0.05]$. In the Overall Figure factor, the average score of the children in the pre-test was $\overline{\mathrm{x}}=2.639$, and $\overline{\mathrm{x}}=3.492$ in the post-test $[\mathrm{t}(182)=-1.947$, $p<0.05]$. In the Overall Creativity Strength Ratings factor, the average score of the children in the pre-test was $\overline{\mathrm{x}}=.941$ and increased to $\overline{\mathrm{x}}=1.451$ in the post-test. This difference is significant in favor of the post-test $[\mathrm{t}(182)=-1.173, p<0.05]$. In the Overall Figural Creativity factor, the average score in the pre-test was $\bar{x}=2.233$ and it increased to $\bar{x}=4.588$ in the post-test. The difference in this factor was found to be significant in favor of the post-test $[\mathrm{t}(180)=-2.011, p<0.05]$. The findings suggest that preschool teacher planned the activities that supported children's creativity for 20 weeks, five days a week. It can be said that the activities planned by the preschool teachers support the creativity of the children.

One of the general properties of the Preschool Curriculum (2013) is prioritizing the development of creativity. The curriculum includes acquirements and indicators related to creativity. It has been stated that preschool teachers should be creative and make efforts to improve children's creativity, support children's creativity with different materials, methods and techniques in the learning process for the curriculum to be implemented in accordance with its purpose. It can be said that teachers acted correctly in terms of creativity when planning and implementing the curriculum.

Gizir Ergen and Köksal Akyol [23] examined the creativity of children who were continuing to kindergarten. The study was carried out with 135 children, 72 girls and 63 boys in the 5-year old age group of independent kindergartens. The Torrance Creative Thinking Test-Figural form A was used to determine the creativity of children. As a result of the research, it was found that the creativity of the children who were going to full-day kindergarten was significantly higher. The results of the study are similar to the results of this study.

Can Yaşar and Aral [24] investigated the effect of preschool education on creative thinking skills. For this purpose, they conducted a study with a total of 210 children, 105 who were attending the preschool for a year and 105 who were newly registered to the preschool. According to the findings obtained from the data collected using the Test for Creative Thinking-Drawing Production 
(TCT-DP), the creative thinking scores of the children attending the preschool were higher than the children who did not receive preschool education. According to the results of the research, preschool education positively supports creative thinking skills. These findings show a similarity to the findings of this research.

Akçum [25] examined the effect of preschool education on the creativity levels of five-six-year-old children. She studied with a total of 100 children, 50 children who received preschool education, 50 children who did not receive preschool education. It was found that the creativity averages of children who received preschool education were significantly higher than those who did not receive. It is seen that the creativity of the children who receive preschool education is positively affected. These findings support the findings of this research.

Yıldız, Özkal, and Çetingöz [26] evaluated the creative potential of children in the age group of 7-8 years, who went and did not go to kindergarten. The study was conducted with 900 students who were in the 1st and 2nd grade in a primary school. As a result, it was found that the creative potential of the children who received preschool education was significantly higher than those who did not receive. These findings are similar to the findings of the research.

\section{Conclusions}

In the research, the effect of preschool education on children's creativity was examined. The results are limited with the children sampled from Ankara City. On the other hand, achievements and type of the activities determined by the MoNE is obligatory to apply for all teachers. In this study, the Torrance Creativity Test's Figural Forms A and B were applied to 184 children, who received education in preschools and kindergartens affiliate to the Ministry of National Education, in 2014-2015. During 20 weeks between the two tests, the Preschool Curriculum (2013) of the Ministry of National Education was implemented by the preschool teachers for five days of the week. Results indicated that the curriculum has positive effect on children's creativity skills.

The results of the studies conducted by Gizir Ergen and Köksal Akyol, Can Yaşar and Aral, Akçum, Yıldız, Özkal and Çetingöz [23, 24, 25, 26] support the result of this research that preschool education positively affects the creativity of children.

In conclusion, it can be said that preschool education improves the creativity of children in a positive way. The recommendations developed in light of the results obtained are presented below.

- The effectiveness of the curriculum was assessed with children attending preschools and kindergartens in Ankara. Therefore, it can be applied to children receiving education in different regions.
- Studies can be conducted to determine the attitudes, beliefs, and practices of preschool teachers about the creativity.

- No control group was used in this study. Control group-designs can be planned in future studies.

- In this study, no persistence study was conducted. Persistence studies can be conducted in order to understand whether the creativity skills acquired in the preschool period are maintained in the subsequent ages.

\section{REFERENCES}

[1] MoNe. Ministry of National Education Regulation on Pre-School Education and Primary Education Institutions, Official Newspaper, 2014, Online available from http://www.resmigazete.gov.tr/eskiler/2014/07/20140726-4 .htm.

[2] MoNe. Early Childhood Education Program. Ministry of National Education, Ankara, 2013, Online available from https://tegm.meb.gov.tr/dosya/okuloncesi/ooproram.pdf.

[3] M. K. Smith. Fostering creativity in the early childhood classroom, Early Childhood Education Journal, Vol.24, No.2, 77-82, 1996

[4] E. Yates, E. Twigg. Developing creativity in early childhood studies students, Thinking Skills and Creativity, Vol. 23, 42-57, 2017.

[5] NACCE. All Our Futures; Creativity, Culture and Education, Department for Education and Employment, London. 1999.

[6] D. Wyse, P. Dowson. The Really Useful Creativity Handbook, Rutledge, London, 2009.

[7] R. Setiawan. The influence of income, experience, and academic qualification on the early childhood education teachers' creativity in Semarang, Indonesia, International Journal of Instruction, Vol.10, No.4, 39-50, 2017.

[8] M. Nilsson, B. Ferholt. Vygotsky's Theories of Play, imagination and creativity in current practice: Gunilla Lindqvist's "creative pedagogy of play" in U. S. kindergartens and Swedish Reggio-Emilia inspired preschools, Perspective, Vol.32, No.3, 919-950, 2014.

[9] A. S. Honig. Promoting Creativity in Young Children, Paper Presented at The Annual Meeting of The Board of Advisors for Scholastic, New York, 2000.

[10] M. D. Prieto, J. Parra, M. Ferrando, C. Ferrandiz, M. R. Bermejo, C. Sanchez. Creative abilities in early childhood, Journal of Early Childhood Research, Vol. 4, No. 3, 277-290, 2006.

[11] G. Duman. Sanat Etkinliği Planlama, Uygulama ve Değerlendirme. N. Aral, G. Duman (Ed.) in Çocuklarda Sanat ve Yaratıcılık. 7th Edition, Nobel Yayıncılık, Ankara. 2018.

[12] M. Faizi, A. K. Azari, S. N. Maleki. Design principles of residental spaces to promote children's creativity, Procedia 
Social and Behavioral Sciences, Vol.35, 468-474, 2012.

[13] F. Ü. Y1ldiz. The Effects of 'programs of experimental creativeness' on the social and cognitive developments of 4-5 aged children, Unpublished Master's Thesis, Konya: Selçuk University Institute of Social Sciences Department of Child Development and Education, 2000.

[14] R. H. P. Cheung. Designing movement activities to develop children's creativity in early childhood education, Early Child Development and Care, Vol. 180, No. 3, 377-385, 2010 .

[15] C. B. Rizi, M. H. Yarmohamadiyan, A. Gholami. The effect group plays on the development of the creativity of six-year children, Procedia Social and Behavioral Sciences, Vol.15, 2137-2141.

[16] V. Alfonso-Benlliure, J. C. Melendez, M. Garcia-Ballesteros. Evaluation of a creativity intervention program for preschoolers, Thinking Skills and Creativity, Vol. 10, 112$120,2013$.

[17] D. Dziedziewicz, D. Oledzka, M. Karwowski. Developing 4-to 6-year-old children's figural creativity using a doodle-book program, Thinking Skills and Creativity, Vol.9, 85-95, 2013.

[18] M. Garaigordobil, L. Berrueco. Effects of a play program on creative thinking of preschool children, The Spain Journal of Psychology, Vol.14, No.2, 608-618, 2011.

[19] Ş. Büyüköztürk, E. Kılıç Çakmak, Ö. E. Akgün, Ş. Karadeniz, F. Demirel. Scientific Research Methods (22 $2^{\text {nd }}$ edition), Pegem Akademi, Ankara. 2016.

[20] V. Sönmez, F. G. Alacapınar. Illustrated Scientific Research Methods ( $4^{\text {th }}$ edition), Anı Yayıncılik, Ankara, 2016.

[21] E. Aslan. Turkish version of Torrance Tests of Creative Thinking, Marmara Üniversitesi Atatürk Eğitim Fakültesi Eğitim Bilimleri Dergisi, Vol.14, 19-40, 2001.

[22] E. Aslan, G. Puccio. Developing and testing A Turkish Version of Torrance's Tests of Creative Thinking: A Study of Adults, Journal of Creative Behavior, Vol.40, No.3, 163-178, 2006.

[23] Z. Gizir Ergen, A. Köksal Akyol. An investigation of creativity among children attending preschools, Journal of Theoretical Educational Science, Vol.5, No.2, 156-170, 2012.

[24] M. Can Yaşar, N. Aral. Yaratıcı düşünce becerilerinde okul öncesi eğitimin etkisi, Kuramsal Eğitimbilim, Vol. 3, No. 2, 201-209, 2010.

[25] Akçum, E. The examination of the effect of pre-school education to the levels of creativity and being ready for learning of 5-6 year old children, Unpublished Master's Thesis, Konya: Selçuk University Institute of Social Sciences Department of Elementary Education, 2005.

[26] V. Yıldız, N. Özkal, D. Çetingöz. Evaluation of creative potential in 7-8 age group children with and without preschool education, Eurasian Journal of Educational Research, Vol.13, No.4, 129-137, 2003. 